\title{
Emotional Symptoms Index
}

National Cancer Institute

\section{Source}

National Cancer Institute. Emotional Symptoms Index. NCI Thesaurus. Code C121283.

An index of the Behavior Assessment System for Children that measures the subject's

overall emotional development. 